\title{
How Social Entrepreneurs Can Create Impact for a Better World
}

\author{
Ozlem Ogutveren Gonul (Drexel University) \\ Zuhal Senyuva (Baskent University)
}

KEYWORDS: social entrepreneurship, Social impact.

Climate change, income inequality, injustice and other vexing social and environmental challenges are changing our thinking and the way businesses operate. As social media helps good and bad news about business practices travel fast, established for-profit companies are taking corporate responsibility seriously. And increasingly, young and socially aware entrepreneurs are aspiring to set up new ventures that address these problems while making money, and social entrepreneurship has become a rapidly growing field. However, despite the good intentions of social entrepreneurs, it remains challenging to measure how much of a difference they are making. In this article, we provide an overview of social entrepreneurship and show options for capturing its impact -- a key part of making the venture sustaining and attracting impact investors who want to channel their money into ventures with strong results.

\section{Defining Social Entrepreneurship}

People have different definitions of social entrepreneurship and how it should be practiced. Some include social activists, non-profit organizations and philanthropists in the social entrepreneurship category, while others include any profit-oriented organizations that produce social outputs for the good of the society. A third view limits social entrepreneurship to profitoriented organizations that are founded with the primary goal to contribute to the solution of a specific social problem, with specific business models to serve this mission. All these distinct types of organizations have different business models and financial sustainability approaches.

In this article we will work with Robinson's (2006) definition of social entrepreneurship, since it is one of the most comprehensive definitions addressing many aspects of the term. Robinson defines social entrepreneurship as, "a process that includes: the identification of a social problem and a specific solution (or a set of solutions) to address it; the evaluation of the social impact, the business model and the sustainability of the venture; and the creation of a social missionoriented for-profit or a business-oriented nonprofit entity that pursues the double (or triple) bottom line" (Robinson, 2006:95). The tendency in the field seems to shift from a non-profit orientation towards a profitoriented approach, with a focus on the social problem and with the realization of increasingly high financial strains. Non-profit organizations relying on donations, grants and governmental support can struggle to maintain financial sustainability to continue their efforts and operations towards solving critical social problems. However, a financially stable and sustainable business may allocate all its time, effort and resources to create innovative solutions in solving the social and environmental problems of a society instead of focusing on providing financial resources.

\section{Scope of Social Entrepreneurship}

Social entrepreneurship is all about creating a positive change in the society, and social entrepreneurs play the role of a change agent and a catalyst for social transformation (Banodia and Dubey, 2017). Peter Drucker indicated that social entrepreneurs change the performance capacity of a society (Gendron, 1996, p. 37). With such large-scale goals, social entrepreneurs target highly intractable social problems (MacMillan and Thompson, 2013) such as poverty, hunger, homelessness, unemployment, environmental issues, sustainable energy, human rights and others. Social entrepreneurs often choose their causes from areas of society that are underserved by government policy and financial support. As a result, they usually work in difficult conditions involving high risk and limited resources in underdeveloped markets, high-risk areas with unreliable infrastructure and even untested technology (MacMillan and Thompson, 2013). Difficult conditions and insufficient resources require exceptional 
planning and an established process to make progress towards scalable, innovative solutions to these extensive social problems.

Social entrepreneurs may have a geographic focus when defining their scope. Many social problems are local, and social entrepreneurs working on local problems may need to operate within their defined territory with specific tools and strategies authentic to the nature of the problem. Other social ventures may be international in their scope and attempt to solve environmental, conservation or sustainability issues across several regions. Some social entrepreneurs aim to develop strategies and movements to impact public policy and funding priorities, with a mission to create national and global solutions to certain social problems.

As a result of an extensive literature review, El Ebrashi (2013, p. 203) proposes that an executable process of social entrepreneurship consists of the following steps:

a) discovering opportunities to eliminate social and institutional barriers and address market failures related to the provision of public goods and distributional equity,

b) experimenting ideas, c) establishing innovative social organizations, d) having clear social outcomes and impact, e) performing activities to achieve the social outcomes and impact, f) working on the social organizations' growth, and g) using specific indicators to measure the success of the organization through achieving social impact. Other critical steps in the process of social entrepreneurship include building the essential networks and securing the resources needed to successfully obtain the social goals set by the social entrepreneur (Thompson, 2002).

\section{Creating Social Value and Impact}

Social ventures produce two critical outcomes to create and sustain social benefits: social impact and social change (El Ebrashi, 2013). Social impact is the effect of an organization's actions and outcomes on the wellbeing of its community and the society at large. Social impact is a general term used to define all social and cultural consequences to human populations of any public or private actions that alter the ways in which people live, work, play, relate to one another, organize to meet their needs, and generally cope as members of society (Burdge and Vanclay, 1996, p. 59).

Social value and social impact address the value added to the community by an organization. Social entrepreneurs make attempts to differentiate between the "outputs," "outcomes" or "impacts" of their organizations. Outputs are the activities listed in an action plan or the objectives defined by an organization, such as providing specialized education for students with specialized needs. Outcomes are the intermediateterm observed effects of the outputs, which initiate the real changes in the society, such as increasing the employment rate of the students with special needs (Mulgan, 2010). Impacts are the long-term results that reflect the mission of an organization through systematic change. Social impacts determine whether a social venture's approach to solving a social problem is actually working (Wolk and Kreitz, 2008). Figure 1 shows the social value proposition model for social ventures incorporating inputs, activities, outputs, outcomes and impacts together.

Planning for and assessing the social impact created by a social venture is critical for many reasons. First, success of a social venture is measured through the sustainable social impact and change it creates, unlike the traditional for-profit businesses for which success is quantified by number of products produced, customers served and financial return through dollars made. Secondly, social entrepreneurs need to attract social impact investors to their cause to secure funding for their ventures. A social impact investor is anyone who provides resources to fund a business plan for enduring social impact (Wolk and Kreitz, 2008). They need evidence that their investment will create measurable social impact and change.

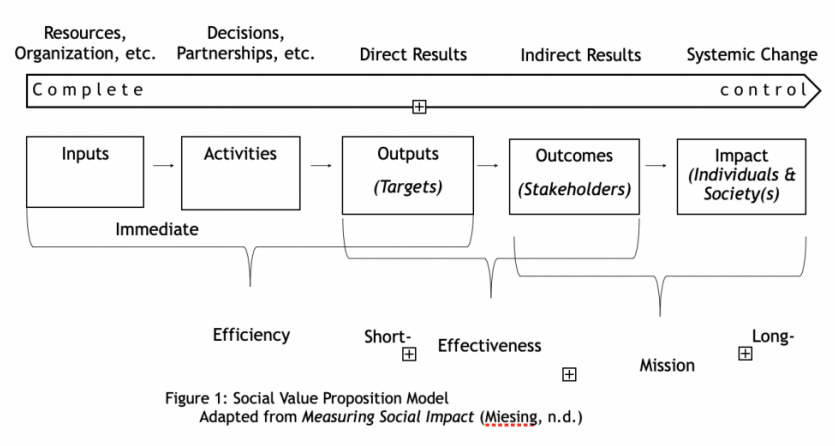

\section{Challenges in Measuring Social Impact}

There are many challenges and problems in developing an efficient social impact measurement and assessment approach. Difficulty in quantifying the impacts, 
complications regarding long-term predictions of social impacts and limitations in resources needed to measure social impacts are the most common issues faced by social entrepreneurs.

\section{Difficulty in quantifying: Social change and} social good are not easy to quantify and formulate for concrete measurement. For example, think about a social venture focused on training uneducated women to help them learn certain skills and become employable. At the end of a determined time period we can quantify the outcomes of the training program as "number of women who participated in the program" or "number of women who were placed in a job with the skills learned from the program." Similarly, a social venture employing and training only former inmates gives this disadvantaged group an opportunity to have a fresh start and a second chance in life. The social outcomes of the venture may be measured as "the number of former inmates employed in a year" or "the number of former inmates who stayed on the job for three consecutive years." However, such an approach of quantifying social outcomes merely measures the short-term results of the social venture and do not reflect the depth of the impact.

2. Difficulty in predicting the long-term impact: If we can observe the results of the above examples over an extended period of time, we would be able to see the deeper effects of these social ventures on the society. For example, if, as a result of the training program for the uneducated women or the employment program for the ex-convicts, their families' standard of living improved, their children could have better education and find better and higher-paying jobs. Such results would have additional positive changes in the society. At a macro level, improvement in economic and social indicators like the "unemployment rate of women" and "recidivism rate of a country" reflects long-term social impact and the positive change in the society. Such results and changes are difficult to predict and quantify to measure the long-term results of a social venture.

3. Cost, time, accuracy and knowledge limitations: A noticeably large number of nonprofits, impact investors and social ventures do not attempt to measure their success in terms of their impact.
Measurement is costly and difficult; measures are actually misleading and dysfunctional; and sometimes the people behind the initiative do not know how to measure the impact (Epstein and Yuthas, 2014). Deciding on what to measure and how to measure it requires special knowledge and expertise, and most of the smallscale social organizations lack the skills needed to measure and interpret results (Epstein and Yuthas, 2014). An additional problem is that measuring long-term impact requires time and money. Furthermore, uncertainty and vagueness in determining the limits of what is measured and figuring out what portion of the change is created through the activities undertaken by the organization adds to the level of complexity. For example, referring to the above example, if (and when) the recidivism rate of a country declines, it is challenging to ascertain how much of the positive societal change can be associated with the activities of a specific social venture.

\section{Approaches to Measuring Social Impact}

Social entrepreneurs are constantly looking for the most appropriate social value and impact measurements for activities undertaken by their ventures. But they disagree on what to measure and how to measure it. Most social entrepreneurs use the common form of "measurement," which is conveying anecdotical stories presenting success examples to their funders and other stakeholders. Although anecdotical stories are critical in disclosing qualitative insights, quantitative data is needed too.

It is important to understand how different stakeholders place value on social and environmental assets in order to develop appropriate measures to assess impacts (Epstein, 2008). Mulgan (2010) summarizes four common methods used by social entrepreneurs in measuring social value and impact:

\section{Cost Benefit Analysis}

Cost Benefit Analysis (CBA), lately called Social Cost Benefit Analysis in the scope of social ventures and projects, is used to determine a project's viability and whether investing in it is a sound decision. The goal in using CBA is to monetarize the value of benefits expected from a project and compare them to the expected costs. It is often used by investors in 
comparing projects with one another and deciding where to invest, based on which option will create the maximum benefit for the society (Mulgan, 2010).

\section{Social Accounting}

Social accounting refers to all "accounts which go beyond the economic" and is used interchangeably with terms such as social responsibility accounting, social audits, corporate social reporting, stakeholder dialogue reporting, environmental accounting and reporting (Gray, 2002). Social accounting requires the implementation of systems to monitor and report processes accounting for creation of social impact. The goal is to build systems to report social performance and make action plans to improve that performance. The system relies on clarifying social objectives and collecting and evaluating qualitative and quantitative data on its outputs. It is important to note that social accounting is a method for continuous improvement on the results produced by an organization (Mulgan, 2010).

\section{Social Return on Investment (SROI)}

$\mathrm{SROI}$ is a financial tool to assess the socio-economic value created. It compares the net social benefits created by a venture to the investment required to generate those benefits over a determined period of time (Millar and Hall, 2013). SROI is a quantitative measure of a company's social and environmental impact (Olsen and Lingane, 2003) and the social impact investors usually demand SROI figures to understand and evaluate the results of their investment with a quantifiable approach. There are two types of SROI. The Evaluative SROI is conducted retrospectively and is based on actual outcomes of an organization; and the Forecast SROI refers to predicted social value to be created if (and when) the intended outcomes are obtained (Mulgar, 2010).

\section{Basic Efficiency Resource (BER) Analysis}

BER analysis seeks to provide a simple framework for evaluating complex multicomponent programs, to evaluate a unit's impact compared to its resources and to offer a relative perspective on performance where the units analyzed are judged in comparison to other peer units (Cugelmon and Otero, 2010). It is a cost-effective way of collecting data through interviews and surveys conducted with staff members, partner organizations, beneficiaries and other stakeholders (Mulgan, 2010). BER is efficient in the sense that in involves many stakeholders and their views in the creation of social impact.

In addition to the methods summarized by Mulgan (2010), many new and discrete measurement approaches have been developed by social entrepreneurs, external auditors, governments and nonprofit organizations. For example, Social Impact Assessment (SIA) is used at a rather macro level, usually by nations, to assess or estimate the social consequences forecasted to follow a specific policy action or a project prior to implementation (Burdge and Vanclay, 1996). Various other approaches such as trained judgment methods (discussions, observations and expert analysis) or qualitative methods (structured interviews and field visits) have been explored to gather in-depth data to extend the measures to a different level. Despite all the efforts, social entrepreneurs still struggle with visualizing the bigger picture and forecasting all the consequences of their ventures.

\section{Next Steps}

Measuring and reporting social impact is found to strategically "improve performance, access to resources, and building organizational legitimacy" (Nicholls 2009) and to increase a social venture's competitiveness. Most social entrepreneurs face the dilemma to decide whether they should devote time and money to measure social impact or to use those resources towards serving their mission. More often than not, they don't channel enough resources into measurement. Entrepreneurs should think about how much of their budget should be allocated to developing affordable and appropriate measurements to increase long-term social impacts.

There is always room for improving social impact measurements and developing more systematic assessment procedures. Following our analysis of the current trends in social entrepreneurship, we have some suggestions for how social entrepreneurs can measure impact.

First, we believe that conducting a Social Needs Analysis prior to taking social action is crucial. Entrepreneurs often can successfully define a social problem and develop action plans towards contributing to the problem they deem critical. Although it is important to frame the social problem, it is also important to find the root causes and consequences of that particular problem. A systematic needs analysis would be essential in determining the real needs or gaps 
between current conditions and the desired conditions in society. Needs analysis should be part of the project planning process to enable the ideal allocation and use of resources, and to reach the maximum level of expected and unforeseen social impact.

Most social ventures choose and use one single approach to measuring social impact. Their preference is usually determined by their limitations in time, resources, skills and knowledge, and their dependence on the impact measurement to manage their stakeholder relations. However, a holistic approach to measuring social impact, using multiple approaches and methods, would present a better view of where they position themselves in contributing to solving the social problem. Using quantitative and qualitative data and methods such as trained judgment, qualitative research, quantification and monetization (Epstein and Yuthas, 2014) together would give the social entrepreneurs a bigger picture of what their ventures have achieved.

Finally, the social entrepreneur should plan and account for a layered social impact. As mentioned before, we can only see the short-term (first layer) outcomes and results of the venture and depend on these outcomes to verify success. Difficult to measure and determine, the longer-term effects (second and even third layer) should be taken into consideration when anticipating the actual impact created by the organization. Only then we can comprehend the real change created in the society.

\section{References}

Banodia, S., \& Dubey, N. (2017). Role of social entrepreneurs as social change agents: an insight. Research Journal of Management Sciences, 6(2), 19-22.

Burdge, R. J., \& Vanclay, F. (1996). Social impact assessment: a contribution to the state-of-the art series. Impact Assessment, 14(1), 59-86.

Cugelman, B., \& Otero, E. (2010). Basic Efficiency Resource: A framework for measuring the relative performance of multi-unit programs. White Paper.

El Ebrashi, R. (2013). Social entrepreneurship theory and sustainable social impact. Social Responsibility Journal, 9(2), 188-209.

Epstein, M.J. (2008). Making sustainability work: Best practices in managing and measuring corporate social, environmental and economic impacts ( $1^{\text {st }}$ ed.). San Francisco: Sheffield, UK: Greenleaf Pub.

Epstein, M. J., and Yuthas, K. (2014). Measuring and Improving Social Impacts: A Guide for Nonprofits, Companies, and Impact Investors. San Francisco: Berrett-Koehler Publishers, 2014. Print.

Gendron, G. (1996). "Flashes of Genius", Inc. 18: 30-38.

Gray, R. (2002). The social accounting project and Accounting Organizations and Society Privileging engagement, imaginings, new accountings and pragmatism over critique? Accounting, organizations and society, 27(7), 687-708.

MacMillan, I. C., \& Thompson, J. D. (2013). The Social Entrepreneur's Playbook, Expanded Edition: Pressure Test, Plan, Launch and Scale Your Social Enterprise. Wharton Digital Press.

Miesing, P. (n.d.). Measuring Social Impact (https://www.albany.edu/faculty/miesing/teaching/socen $\mathrm{t} / 7 \% 20$ Measuring\%20Social\%20lmpact.pdf).(retrieved on $12 / 16 / 2019$ ).

Millar, R., \& Hall, K. (2013). Social return on investment (SROI) and performance measurement: The opportunities and barriers for social enterprises in health and social care. Public Management Review, 15(6), 923-941.

Mulgan, G. (2010). Measuring social value. Stanford Soc Innov Rev, 8(3), 38-43.

Nicholls, A. 2009. 'We do good things, don't we?': 'Blended Value Accounting' in social entrepreneurship.' Accounting, Organizations and Society, 34(6-7): 755-769.

Olsen, S. and Lingane, A. (2003). Social return on investment: Standard Guidelines. Working Paper Series, UC Berkeley.

Robinson, J. (2006), "Navigating social and institutional barriers to markets: how social entrepreneurs identify and evaluate opportunities", in Mair, J., Robinson, J. and Hockerts, K. (Eds), Social Entrepreneurship, Macmillan, New York, NY.

Thompson, J. L. (2002). The world of the social 
entrepreneur. International journal of public sector management, 15(5), 412-431.

Wolk, A., \& Kreitz, K. (2008). Business Planning for enduring social impact: A Social-Entrepreneurial Approach to solving social problems. Root Cause. 